\title{
Adequacy of Intercultural Dialogue Via Free Translations of Russian Poetry
}

\author{
Anastasia V. Sycheva* \\ North-Eastern State University \\ 13 Portovaya Str., Magadan, 685000, Russia
}

Received 15.09.2016, received in revised form 11.10.2016, accepted 19.01.2017

The article aims to prove the adequacy of intercultural communication realized with free translations. The method of comparative linguistic analysis of the original text and its translation used in the article defines free English translations of Bulat Okudzhava's poems taking part in the intercultural dialogue of Russian and English-speaking readers. Consequently, the carried out analysis outlines main features of free translations. The most prominent among them are: the adequacy coefficient $>20 \%$, a system of maintained semantic connections with the original, a relatively high artistic value of the translation. As a result, the identified features mark free translations very high in the hierarchy of poetic translation typology and recognize their significant role in an adequate dialoguing of intercultural communicants. The material of this research can be applied in the theory of both literary translation and intercultural communication.

Keywords: free translation, original, text, translator, equivalent, meaning, adequacy ratio, adequacy coefficient, intercultural dialogue.

DOI: 10.17516/1997-1370-0050.

Research area: philology; culture studies.

Russian and foreign linguists and researchers have been investigating the problem of free translations for many decades. As a result, nowadays the theory of translation has many definitions of the term "free translation" at its disposal. R. R. Chaikovskii, for example, defines a free translation as a piece of poetry written on the basis of a foreign original, but with different stylistic parameters, low accuracy and high freedom rate (Chaikovskii, 1997: 70, 71). From his point of view, this type of translation is one of the most popular among the translators as it provides them with a certain degree of freedom in reconstructing the main idea and the poetic form of the source text. Moreover, free translations enable translators to show their understanding of the original to the foreign readers.

R. R. Chaikovskii' s vision of the problem findsreflection in the opinion of anotherresearcher of free translations L. L. Neliubin who considers them to be "subjective" translations (Neliubin, 2003: 32). The subjectivity of free translations is also proved in S. B.Khristoforova's definition: "A free translation is a translation, characterized either by some additional thematic and stylistic elements which are absent in the original or

(c) Siberian Federal University. All rights reserved

* Corresponding author E-mail address: nastik-80@mail.ru 
by the omission of elements significant for the original" (Khristoforova, 2002: 165). The following theoretical framework underlines high freedom and subjectivity of free translations, but doesn't justify the level of adequacy of these translations in the process of intercultural communication. To find out their pertinence in the interlinguistic dialogue it's necessary to apply the method of comparative linguistic and stylistic analysis of the original and its foreign language version. Poems by Bulat Okudzhava and their English translations serve the material for the study.

For instance, B. Okudzhava's "Main Song" and its English analogue by A. Vagapov are to be compared:

Наверное, самую лучшую / на этой земной стороне / хожу я и песенку слушаю / она шевельнулась во мне. // Она еще очень неспетая. /Оназелена, кактрава. /Но чудится музыка светлая, / и строго ложатся слова. // Сквозь время, что мною не пройдено, / сквозь смех наш короткий и плач / я слышу: выводит мелодию /какой-то грядущий трубач. // Легко, необычно и весело // кружит над скрещеньем дорог // та, самая главная песенка, / которую спеть я не смог (Окуджава, 2006: 119).

Wherever I go I can hear / the song that has turned me on, I the best one I heard over here, / I listen again to the song. // The singing requires more effort, / it's raw and unripe, in fact. / However, the music is perfect, / the lyric precise and exact. // Through times yet unseen and / through transient tears and smiles / I hear a trumpeter blowing / the tune in the best of styles. // Unusual, light and so pleasant, / it whirls over roads in a spin, / this main song which up to the present / I haven't been able to sing (Vagapov, 2006: 105).

Overall, A. Vagapov reproduces the original contents in translation. However, he changes the semantics of the first line in the second stanza
(Она еще очень неспетая - The singing requires more effort). Moreover, he omits the comparison and some metaphorical expressions: Она зелена, как трава - it's (song) raw and unripe; над скрещеньем дорог - over roads; какой-то грядущий трубач - a trumpeter. In addition, Okudzhava's music is light, and laughter is short, while in Vagapov's translation the music is perfect (flawless), and instead of laughter he uses transient tears and smiles.

What is more, the translator doesn't follow the original amphibrach. The break in the rhythm is observed in the second lines of the first and the second quatrains. In the third stanza: the first line is four syllables shorter than the original, the last line is one syllable shorter. As for the syllabic volume, the rhymes of the translation are different from original dactylic verse and male rhyme. However, the cross-rhyme is saved. In the third quatrain Vagapov leaves the first and the third lines unrhymed, but saves the cross-male rhyme in the second and the final lines. This indicates a certain degree of interpreter's freedom, who, therefore, gives the reader his own interpretation of the original.

Besides, the comparative analysis of glossaries also refers A. Vagapov's "Main Song" to free translations. The original lexical matrix shows that the text comprises 48 words: 13 nouns, 10 verbs, 11 pronouns, 8 adjectives, and 5 adverbs and 1 participle. Among 13 nouns the word песенка is used twice. Among 10 verbs we find the verb слушать twice. Among 11 pronouns, она and $s$ are mentioned 3 times.

A. Vagapov's translation has 14 nouns, 12 verbs, 9 pronouns, 12 adjectives, ladverb and 3 participles. Among 14 nouns he uses the word song twice. Among 12 verbs, he uses the verb to hear twice. Among 9 pronouns $I$ and it are mentioned twice. Moreover, there are 8 added lexical items (for instance, in fact, again, etc.). The total number of words is 59 . 
Table 1. Lexical Matrix of Comparative Analysis

\begin{tabular}{|l|c|c|c|c|c|c|c|}
\hline \multicolumn{1}{|c|}{ Author } & Words & $\begin{array}{c}\text { Equivalents } \\
\text { (AR) }\end{array}$ & Correspondences & $\begin{array}{c}\text { Contextual } \\
\text { variants }\end{array}$ & Replacements & $\begin{array}{c}\text { Added } \\
\text { lexical } \\
\text { items }\end{array}$ & Omissions \\
\hline B. Okudzhava & 100 & & & & & & \\
\hline A. Vagapov & 122,9 & 30,5 & 18,7 & 12,5 & 23,9 & 37,3 & 10,4 \\
\hline
\end{tabular}

The comparative lexical analysis of B. Okudzhava's "Main Song" and its English version shows that the translator uses part of speech replacement method. For example, the pronoun is translated with the vernal noun (она singing); adverbs are replaced with adjectives (легко, необычно и весело - unusual, light and so pleasant), etc. Table 1 presents lexical comparison of the original and its English analogue in percentage.

As we can see, the accuracy ratio (AR) is $30,5 \%$. Consequently, the adequacy coefficient is rather high $-49,2 \%$. S. B. Khristoforova notices that in R. R. Chaikovskii's typology of poetic translations, the accuracy ratio barrier defining free translations isn't mentioned, but she assumes that the value of $50 \%$ may serve as this dividing barrier separating free and adequate translations (Khristoforova, 2002: 163). It's worth saying that in R. R. Chaikovskii's classification the accuracy ratio is determined by adding equivalents and correspondences, which in our case actually means the adequacy coefficient.

The translation of B. Okudzhava's poem “The Poets Do Not Have Rivals..." by E. Bonver can either serve as an example of free translations. Let's compare first two stanzas of the original and its English version:

У поэта соперников нету / ни на улице и ни в судьбе. / И когда он кричит всему свету, / это он не о вас - о себе. // Руки тонкие к небу возносит, / жизнь и силь по капле губя. / Догорает, прощения просит: / это он не за вас - за себя (Okudzhava, 2001: 419).
Bard doesn't have to his art competition: / On a street or in fate - it is safe. / And when he sends to world his petition, / He deplores not you - but himself. I/ Stretching his fragile arms to the heaven, / Slowly killing himself all life through, / He implores to be just forgiven: / Asks about himself, but not-you (Bonver, 2016).

The beginning of the poem undergoes some semantic shift in English as E. Bonver narrows the concept poet using its correspondence bard (a singer performing songs of his/her own composition with the accompaniment of the guitar). In other words, he applies the specification method. Specification is a transformational operation, when the interpreter replaces the notion having a broader meaning and less complex content, with the notion of a more limited meaning, but a more complex content. Thus, specification necessarily implies the addition of new features to the object described in the original text. A linguistic form, a word or a phrase naming a less general idea in the translated text, appears a hyponym to the linguistic form in the original text, therefore, this transformational operation can also be defined as hyponymic conversion (Garbovskii, 2007: 433). The phenomenon of hyponymy in the theory of translation is closely connected to hyperonymy and transformational operation of generalization, which means lexical and semantic replacement of foreign lexical units having a more narrow meaning, with units of a wider meaning (Komissarov, 1990: 246).

The opinion of many linguists about the problems of generalization and specification 
varies. So, N. K. Garbovskii writes that lexical meanings encased in an original text undergo some crucial changes because of hypohyperonymical transformation. V. S. Vinogradov believes that the emergence of semantically incomplete equivalents in translation is in no way evidence of any semantic loss as thesemanticinformationataphrase-levelorawider context is completely saved. He writes that in the same manner we should consider semantically incomplete equivalents within a word (extension or narrowing of its notion in relation to the notion of a word in the source language does not lead to any serious semantic distortion - as in the end the referent in both cases remains the same). Therefore, cross-language metonymic transformation does not destroy the general lexical meaning of correspondences (Vinogradov, 2004: 84, 85).

We support N. K. Garbovskii's point of view about a partial change in the word meaning due to specification and generalization. Moreover, there is an equivalent to the word поэm in the English language - a poet. The lexemes поэт - a poet are not only similar in their lexical form, but also comprise equal meanings (concepts). According to Garbovskii, the words with equal semantic volume are those lexemes, which are full equivalents in a pair of languages, i.e. the interlinguistic identities (Garbovskii, 2007: 342). In this case, the Russian word nоэm and the English word poet have identical semantic volume.

Using Y. Solodub's terminology, the words nоэm and poet have $A$ semantic attraction. The semantic attraction is defined in the broad sense as "mutual attraction" of two words with semantically close meanings (Solodub, 2005: 104). Such words can easily substitute each other in translation. Actually, they are equivalents. However, the author specifies that the linguistic phenomenon of semantic attraction is often subjective and while translating can lead to errors in the word meaning. Accordingly, it'll be more correct to say that - the lexemes поэm - poet have a high degree of semantic attraction, while the lexemes поэm - bard are characterized by a relative semantic attraction. Nevertheless, the correspondence bard used by E. Bonver does not crucially destroy the general idea of the text.

Though the translator introduces some elements: art, petition, etc. and omits such lexical units as: cuльl, догорает, etc., he manages to preserve the semantic connection with the original. His translation contains 37 words (independent parts of speech), in contrast to Okudzhava's 28 meaningful words. 11 words are translated with their direct equivalents. Consequently, the accuracy ratio of the glossary is $39,2 \%$ plus 7, $1 \%$ of English correspondences. Thus, the adequacy coefficient is $46,3 \%$.

The original poem written in anapest looks like this - ー rhyme is cross-male and female. E. Bonver reproduces these features in the first stanza, but the last line of the quatrains presents a rhythmic break. The second stanza is identical to Okudzhava's in the syllabic volume of the rhyme and the method of rhyming, but the first line in the translation has dactylic verse, and the final is written in two-syllabic choreus. In addition, there are rhythmic irregularities in the third line of Bonver's translation. Such deviations from the original are also met in the third and the fourth quatrains of translation. E. Bonver's translation is rather close to the original text and conveys its semantics, the structure of the poem, its style and emotional coloring. Along with this, E. Bonver adds some elements non-existing in Okudzhava's text. Besides, the interpreter failed to withstand the original verse to the full degree; however, the adequacy coefficient almost reaches the barrier of $50 \%$. All these observations make the translation of E. Bonver free. 
The analyzed translations of B. Okudzhava's poems fall under the definition of free translations. This differentiation became possible due to the benefits of the following study and its results, i. e. the distinguished fundamental indicators of a free translation: adequacy coefficient $>20 \%$, a system of semantic relationships with the original text, relatively high artistic value of the translation.

To sum it up, it's worth stating that free translations are adapted for foreign readers and reproduce both the form of the original texts and their coherent semantics with few irregularities. High quality translations require either the profound knowledge of native and foreign languages, or the specific national peculiarities of communicating cultures. Free translations can be estimated as high quality translations; therefore, they contribute to the process of adequate intercultural interaction.

\section{References}

Bonver, Y. (2016). Translations of Poetry by Bulat Okudzhava. Available at: http://www. poetryloverspage.com/yevgeny/okudzhava.html/ (accessed 14 March 2016).

Chaikovskii, R.R. (1997). Realnosti poeticheskogo perevoda (tipologicheskie i sociologicheskie aspekty) [Realities of Poetical Translation (typological and sociological aspects)]. Magadan, Kordis, $197 \mathrm{p}$.

Garbovskii, N. K. (2007). Teoria perevoda [The Theory of Translation]. Moscow, Izd-vo MGU, $544 \mathrm{p}$.

Khristoforova, S. B. (2002). Poeziia Bulata Okudzhavy v nemetsikh perevodakh (istoricheskie, stilistiko-sopostavitelnye $i$ perevodcheskie aspekty). Dis. ... kand. filol. nauk. Magadan [BulatOkudzhava's Poerty in German-Language Translations (Historical, Stylistic-Comparative and Translational Aspects). Cand.sc. phil. diss.]. 251 p.

Komissarov, V. N. (1990). Teoriia perevoda (lingvisticheskie aspekty) [The Theory of Translation (linguistic aspects)]. M., Vyssh.shk., 253 p.

Neliubin, L. L. (2003). Tolkovyi perevodovedcheskii slovar [Defining Translational Dictionary]. M., Flinta, Nauka, 220 p.

Okudzhava, B. Sh. (2001). Stihotvoreniia [Poems]. SPb., Akademicheskii proekt, 712 p.

Okudzhava, B. Sh. (2006). Stihotvoreniia [Poems]. M., Jeksmo, 480 p.

Solodub, Iu. P. (2005). Teoriia I praktika khudozhestvennogo perevoda [Theory and Practice of Literary Translation]. M., Akademiia, 304 p.

Vagapov, A. (2006). Popular Poetry Pages. An Anthology of Literary Translations.Pskov, Publishing House of Regional Center of People's Creative Work, 108-140.

Vinogradov, V. S. (2004). Perevod: Obshhie I leksicheskie voprosy [Translation: General and Lexical Problems]. Moscow, KDU, 240 p. 


\title{
К вопросу об адекватности \\ межкультурного диалога посредством \\ вольных переводов русской поэзии
}

\author{
А.В. Сычёва \\ Северо-Восточный государственный университет \\ Россия, 685000, Магадан, ул. Портовая, 13
}

Статья представляет анализ адекватности межкультурного общения, осуществляемого посредством вольных переводов. Метод компаративного лингвистического анализа оригинала и перевода, применяемый в статье, дифферениирует вольные английские переводы стихотворений Булата Окуджавы, которые способствуют межкультурному взаимодействию русских и англоязычных читателей. Проведенный анализ выявляет основные ведущие черты вольных переводов. Наиболее значимые из них - коэффициент адекватности не ниже 20 \%, сохранение системы семантических связей с исходным текстом, относительная художественная ценность самого перевода. Выявленные характеристики определяют высокое место вольных переводов в иерархии поэтического перевода и подтверждают их значимую роль в осуществлении адекватного диалога культур-коммуникантов. Материал исследования может быть использован как в теории литературного перевода, так и в области межкультурной коммуникации.

Ключевые слова: вольный перевод, оригинал, текст, переводчик, эквивалент, смысл, коэффицичент точности, коэффициент адекватности, межкультурный диалог.

Научная специальность: 10.00.00 - филологические науки; 24.00.00 - культурология. 